\title{
Addis Ababa/Finfinee: A Blueprint towards Twin-city Administration
}

\author{
Qabeenyi biyya keenyaa, qabiyyeen qabeenyaa; \\ Yookaan qixxee hintaane, yookaan cittee hin baane, \\ Akkuma isa durii, akkuma isa durii! \\ $\sim$ Zelalem Abera, 2000 \\ Zelalem T. Sirna*
}

\begin{abstract}
This article analyses the challenge of Addis Ababa's double status - both as capital of Ethiopia and that of the Regional State of Oromia. It delves into the unresolved issue of the special interest of Oromia in Addis Ababa/Finfinnee. This article propounds that, where there is no separate capital city administration directly responsible to the State of Oromia, it is constitutionally nonsensical and hierarchically incongruent to require the State of Oromia to join hands with the Addis Ababa city government for joint administration. Thus, it seeks to address the so-called "special interest" of Oromia in Addis Ababa/Finfinnee through two-city administrations. This stems from a critical reading of the constitutional provision which calls for the establishment of joint administration of Addis Ababa/Finfinnee (see: Art 49 (5) of the FDRE Constitution). Furthermore, the Indian model of city administration is taken as a lesson to supplement twin-city administration. This article finds that, for the State of Oromia to ensure not only the so-called "special interest in Addis Ababa" but most importantly its right to the city, it shall, a fortiori, undertake a structural adjustment.
\end{abstract}

Keywords: Addis Ababa/Finfinnee, India, Special Interest, Twin-city Administration DOI: https://dx.doi.org/10.4314/ejossah.v14i1.4

\footnotetext{
* PhD Candidate, Coimbra University, Portugal and Lecturer, Department of Law, Salale University, email: zelalem.tesfaye430@ gmail.com, Tel: +251912157089

This work is licensed to the publisher under the Creative Commons Attribution-NonCommercialNoDerivs License.
} 


\section{Introduction}

Capital cities are arenas of vast economic, environmental, political and cultural wealth and diversity - which often benefit a few while the majority are exposed to massive evictions, segregation, and resulting deterioration of social coexistence ${ }^{1}$ (World Charter Right to the City, 2005: 1). While David Harvey calls it "accumulation by dispossession" (Harvey, 2008: 12), Fouad calls it development by dispossession (Makki, 2013: 79-103). Often, where urban planning is undertaken without the inhabitants and implemented through violent means, the surrounding populations are often pushed to the outskirts of the city (ErdiLelandais, 2014).

The reality in Addis Ababa, one of the renowned capitals of Africa, is not far from these underpinnings. Markakis notes that where the feudal regime in Ethiopia had established landlord versus serf relations, the current label is "investor" versus "labourer" relations - where the former is nothing but a "modern landlord" and the latter are reduced to "modern serfs" working to win their daily bread. Nowadays, the compensation paid to these evicted individuals is scanty. ${ }^{2}$ This fact has led the farmers surrounding Addis Ababa to the state of selling out their holdings in the black market - still unfair but far better than the insignificant compensation the socalled investors pay. ${ }^{3}$ Beside illicit eviction of farmers at outskirts of the capital

\footnotetext{
${ }^{1}$ Article 11 of the World Charter Right to the City also provides for multi-cultural coexistence and the responsibility of the state to "respecting diversity and preserving the cultural memory and identity of all citizens free of discrimination of any kind" (WCRC 2005).

${ }^{2}$ Tsegaye (2016) holds that under the current regime, hundreds of thousands of Oromo people surrounding Addis Ababa have been evicted with no or little compensation and their lands were given to local and foreign companies. Previously hard-working and independent farmers and their children were effectively reduced to daily labourers, guards and homeless. This fact generated deep discontent towards the regime in power. For example, suburbs such as: Labu, the Laga-tafo, Mari, Bole-Bulbula, Buraayyuu, Sabbata, Sululta, Akaki-Qalittii legally belong to the State of Oromia. However, all these areas were kept as the backyards of the central authority in the name of "Industrial Zones", "Recreational Parks", and "Investment". See also: Rajac, and Lall 2009.

${ }^{3}$ See: Proclamation No. 455/2005 on Expropriation of Landholdings for public purposes and Payment of Compensation. Although this proclamation was enacted to regulate the question of expropriation of lands, it does not deal with the amount of compensation payable to collective land holdings.
} 
city, the industrial plants in and surrounding Addis Ababa/Finfinnee release untreated wastes (in solid, liquid, and gaseous forms) directly to the surrounding environment (Addis, 2006).

Adding to the already entrenched grievances and discontents over urban land issue surrounding Addis Ababa/Finfinnee, the so called Addis Ababa Integrated Development Master plan was televised in April 2014. ${ }^{4}$ It was aimed at expanding the territorial boundaries of the capital city, "increasing the city to twenty times its present official size (i.e. 54,000 hectares) by taking over prime agricultural land from Oromo farmers." ${ }^{, 5}$ In the face of ruling party's defiance to implement the Master Plan, the opposition against the Master Plan was widespread across Oromia. ${ }^{6}$

${ }^{4}$ The Master Plan was presented as already designed in agreement with the State of Oromia; mainly, for the transformation of the surrounding community. In fact, the federal government was paternalistic. The Tigray Peoples' Liberation Front (TPLF) leaders and some OPDO figures made it clear that the Master Plan will inevitably be implemented. At first, the statement was also seen suspiciously and the practice of the state was also not in line with its statement. The fact that the declaration of the state of emergency and the ruthless measures that followed have relatively winded up the tense state-society relation. In the meantime, however, the issue of Oromia's special interest in Addis Ababa was also raised by the State of Oromia.

${ }^{5}$ OSA, December 9, 2015 Statement on the Addis Ababa Integrated Development Master Plan and Oromo Student Protests against its Implementation. Even, some of the members of the Oromo Peoples Democratic Organization (OPDO now renamed as ODP) also openly opposed noting that: "The issue of Addis Ababa and its surrounding towns is not only the issue of a city. It is rather about identity. We can raise this issue from several dimensions. The Master Plan must promote the culture, language, history, and political and economic interests of the Oromo. We know well how the development of Addis Ababa began and where it is today. That is why we are saying that the Master Plan should have been based on the Constitution. We do not need the kind of master plan that pushes away the farmers. Instead, we need a plan that embraces the farmers and their children in the development process. It has to be a plan that the local community and the regional government accept and endorse" (Translated from Takele Uma's speech on April 2014. See also: https://www.youtube.com/watch?v=HVo_9aOnQME (Accessed on August 18/2017).

${ }^{6}$ In fact, the position of the ruling regime was inconsistent with Article 43(2) and Article 89 of the FDRE Constitution, which provides that the people have the right to be consulted and involved in development projects. In most cases, the citizens are forced out of their homes without due compensation and only the lucky ones can get a bit. The case of the 
In the meantime, the EPRDF attempted to enact the "special interest of Oromia in Addis Ababa" into law as part and parcel of appeasing political discontent, and to reinstall its political legitimacy. The draft proclamation was submitted to the Council of Ministers in June, 2017. It was finally sent to the House of People's Representatives for final promulgation. Before its adoption, however, the draft proclamation was leaked through social media and found that what constitutes a "special" interest was not set, the issue of "joint administration" was not considered, and above all there was no credible deliberation among the public. Thus, the parliament was forced to postpone its promulgation for an indefinite period of time. ${ }^{7}$

Having said, the main objective of this paper is not to discuss the multifaceted issues in relation to Addis Ababa/Finfinnee vis-à-vis Oromia Regional State. Rather it seeks to address the controversial issue of the "special interest of Oromia in Addis Ababa" through twin-city administration. The basis of this proposal stems from the constitutional arrangement that calls for the establishment of joint administration of Addis Ababa/Finfinnee.

This paper is presented in four sections. The first section sets Addis Ababa/Finfinnee as a hub of political fever. The second section discusses the so called "special interest of Oromia regional state in Addis Ababa and elucidates the impotent principle of joint administration. The third section introduces the experience of Delhi and New Delhi administration of India. Drawing some lessons from the Indian case it proposes a two-city administration as a way-out. Finally, concluding remarks are forwarded.

\footnotetext{
"\#Oromoprotests" (from 2014 to 2016) is one instance where the Master Plan was resisted and the government was finally forced to revoke it.

7 The "initiative" to legislate "the special interest" of Oromia in Addis Ababa/Finfinnee was secretive and the public did not deliberate over. The more it was kept hidden, the more it generated public distrust towards the regime and the draft legislation was finally aborted. However, among others, the draft proclamation provides that Addis Ababa shall also be named Finfinnee; the past names of places in the capital city shall be reinstated - for example: Mercato as Agamsa; Piassa as Birbirsa Goro; Mexico as Chafe Anani; Kasanchis as Karsa, etcetera. However, the critics hold that these are not "special" and it cannot address the historical wounds and the deep mistrust between the Oromo and the EPRDF regime.
} 


\section{Addis Ababa/Finfinnee: A Nucleus of Political Malady?}

Addis Ababa/Finfinnee was inaugurated in the late $19^{\text {th }}$ Century through biological and cultural "genocide" ${ }^{8}$ of the indigenous Oromo clans, such as Gulalle, Eka and Galan. Their homes were destroyed and their lands partitioned among the emperor Menelik and the dignitaries ${ }^{9}$ (Harris, 1844). In 1888, the place previously known among the Oromo as Finfinnee was renamed as "Addis Ababa." ${ }^{\text {"10 }}$ Finfinnee, the original name of Addis Ababa/Finfinnee, was a socio-political centre of the Oromo taken away from the latter by Emperor Menelik II through the use of force (Bulatovich, 2000).

Tsegaye Regassa describes this event as remembered by the Oromo as a moment of material and cultural loss, politico-military humiliation, dispossession of land, disorientation of one's way of life, expropriation of the means of livelihood, and wanton destruction of the natural environment (Tsegaye, 2016). Nevertheless, the historical injustice, and the deep division between the "Ethiopianists" (thesis) and the "Oromianists" (anti-thesis) over Addis

${ }^{8}$ Tsegaye expresses the reality of the Oromo in Addis Ababa/Finfinnee as follows: an invisible, non-speaking, non-acting other who inhabits the interior of the territory but the exterior of the polity ... the present absence and the absent presence at a time (Tsegaye, 2016).

${ }^{9}$ A documentary entitled "Firoomanii Gamnomuuu" by OBS Television. The documentary has essential interviews and visual materials clearly indicating the first Oromo Communities were, among others, the Eka. One of the families of the Eka community was Tufa Arado's family. Tufa Arado had nine children, namely; Habebe Tufa, Birra Tufa, Malka Tufa, Dadhi Tufa, G/Amla Tufa, Oda Tufa, Gada Tufa, Beyene Tufa, Moru Tufa and Gurmu Tufa. Habebe Tufa was the first son of Tufa who was given to Emperor Menelik at age seven and later became one of the generals during Ethio-Italian war (Adwa) and named as Fitwurari Habebe Tufa Arado. Since Habebe was brought up Menelik's palace, before his death, he asked the then Emperor that Lij Iyasu be the next leader of Ethiopia. Nevertheless, to this date, there are grand children of Fitwurari Habebe and they have given their interviews to OBS television.

See also: https://www.youtube.com/watch?v=Kos7WP7Zopc (Accessed on December 13, 2018)

${ }^{10}$ The Oromo call their capital city as Finfinnee, etymologically has two terms "finna" meaning "gift" and "finne" meaning, "we brought" - together, "we brought gifts!" (Ezikiel Gebisa, 2015, speech at OSA Conference). Whereas, "Addis Ababa" is an Amharic word, which means "new flower". 
Ababa/Finfinnee has proceeded under the current regime without genuine political consensus.

Pre-1991, Addis Ababa/Finfinnee had the status of "city state." However, the Federal Democratic Republic of Ethiopia constitution, here in after the 1995 FDRE constitution, reduced it to a self-governing city responsible to the federal government. ${ }^{11}$ The constitution also stipulated that Addis Ababa/Finfinnee is in the heartland of the Oromia regional state. In spite of this fact, in 2001, the ruling party passed a decision that the capital of the State of Oromia to be moved to Adama town, $85 \mathrm{~km}$ away from Addis Ababa/Finfinnee; the second largest city in Oromia. Back then, the Oromo nationalists in different universities in Ethiopia opposed the decision - and as a result, many students in Addis Ababa University were dismissed from their studies and many disappeared. Following the 2005 landmark victory of the CDU (Coalition for Democracy and Unity) in Addis Ababa/Finfinnee, the Federal government restored the capital of Oromia to Addis Ababa/Finfinnee. This was never ever intended to give the State of Oromia its rightful place. Rather, replenishing the historical rivalry between the Oromo and the Amhara (which most of them were members of CDU) the federal government effectively played the Oromo against the Amhara.

In the last decade, the TPLF-led EPRDF (Ethiopian Peoples' Revolutionary Democratic Front) escalated the eviction of peasants from their ancestral land, often in the name of urbanization and development. ${ }^{12}$ This fact had a cover of the constitutional provision which reads "... rural and urban land, as well as all natural resources, is exclusively vested in the State and in the peoples of Ethiopia" (Article 40 (3) of FDRE Constitution).

The proponents of this provision reiterate the historical feudal system of the country where the gun bearers and landlords severely oppressed peasants to serfs, arguing that subjugating the land to private ownership would be tantamount to the restoration of the feudal system. This led to state-driven land alienation as opposed to market-led land alienation" (Muradu, 2014: 17). Whereas the opponents argued that, land should be privately owned. They argued for the autonomy of individuals

\footnotetext{
${ }^{11}$ See: Article 49 (1) (3) of the 1995 Federal Democratic Republic of Ethiopian Constitution. Proclamation No. 1/1995

${ }^{12}$ Among the undemocratic regimes of the global south, and in other parts of the world, eviction under the façade of "development" has become a common practice (Azuela, 2009; Rajack, 2009; Myers, 2011; Harvey, 2012; Varahney, 1998; Samara and Roshan, 2013).
} 
to own and dispose it in any form they deem necessary. ${ }^{13}$ However, Bekele Gerba rightly observed that:

Let's be honest. Today, does the land belong to the people? Does it belong to the state? In our assessment, land does neither belong to the state nor to the people. Land is the ruling party elite's private property. ... In relation to land, our citizenship in Ethiopia has four layers: first-class citizens, those who authorize; second-class citizens, those who have access to the land; third-class citizens, those who watch the drama; and the fourth-class citizens, those who are evicted, poor peasants. ${ }^{14}$

In this hierarchy of "citizenship" business organizations or "investors" (domestic and multinational) are given priority in relation to access to land in the name of "development." Where the third category are the spectators, the fourth group of citizens are those who pay the price, the evicted citizens who are doomed to face "landlessness, joblessness, homelessness, marginalization, food insecurity, increased morbidity and mortality, loss of access to common property and services, and social disarticulation" (IDCM, 2010). They are those who were once owners of the land and now are subjected to daily labour at wages of below a dollar per day.

From an optimistic stance, however, the right to the city opens a space for "citadins", to quote Lefebvre, to take part in decision-making processes. For Purcell, the right to the city encompasses "the right to participation and the right to appropriation" (Prucell, 2002: 102). Harvey perceives the right to city as the

\footnotetext{
${ }^{13}$ However, for a keen observer of land rights under the EPRDF, there is similarity with the land tenure system under the Dergue regime. For instance, Gemetchu Megersa saw that the land proclamation was meant: To mislead the land starved Oromo population with empty promises that land has now become theirs. ... to give the new Abyssinian ruling elite absolute control over the Oromo land and therefore over the Oromo economy, natural resources and man power without which Abyssinian political control and colonial domination could not be effective (Gemetchu, 1993: 289).

${ }^{14}$ Bekele Gerba is one of the prominent opposition political figures, vice-chair person of Oromia Federalist Congress, and he was a prisoner of conscience for over five years in infamous Ethiopian Maekelawi penitentiary. After a series of social unrest and consequent political crisis, he was finally released on February 14, 2018. See his speech at: https://www.youtube.com/watch?v=YY4EuwFNO_8 (Accessed on May 28, 2017).
} 
access to power of "shaping the processes of urbanization" (Harvey, 2008: 5). Mark Purcell notes that "Lefebvre's right to the city is not a panacea ... it is like a cry and a demand ... a transformed and renewed right to urban life" (Lefebvre, 1991 quoted in Purcell, 2002: 99-108).

\section{The "Special Interest" of Oromia in Addis Ababa}

The "special interest" clause was first introduced in the National/Regional Selfgovernment Proclamation No. 07/1992. Article 3 (4) of the proclamation reads:

The special interests and political right of the Oromo over Region Thirteen [Harari] and Region Fourteen [Addis Ababa] are reserved. These Regions shall be accountable to the Central Transitional Government and the relations of these SelfGovernments with the Central Transitional Government shall be prescribed in detail by a special law. ${ }^{15}$

Back then, Addis Ababa/Finfinnee was designated as a city state. In the 1995 Constitution, however, where Harari became an autonomous regional state, Addis Ababa's status was reduced to the seat of the Federal Government and the "capital" of Oromia. Moreover, the FDRE constitution consolidated the State of Oromia and the Federal government into one space: Addis Ababa. These are two entities at two ends of the pole - pulling and pushing each other on the same territory. ${ }^{16}$ Art. 49 (3) of the FDRE constitution made the administration of Addis Ababa/Finfinnee solely responsible for the Federal Government. This

\footnotetext{
${ }^{15}$ Proclamation No. 7/1992 of 14 January 1992: The National/Regional Self-Governments Establishment Proclamation No. 7/1992.

${ }^{16}$ Let's explain this situation through the following metaphor. One of my friends, $O$, loves to watch movies, play football, and wants to lead a balanced life. We have a friend, $D$, often so busy, who leads a stressful life. One day this friend of mine said to me, "imagine what would happen if D's body was partly attached to my body ... when I need to watch movies, play football or have fun; D's interest to always engage in stressful activities preoccupies me ... can you imagine how my life would be miserable?!" The author perceives the controversy between the Federal government and the state of Oromia over Addis Ababa in similar fashion. Unless both organs come to agreement to establish a system both can work autonomously on matters that are specific to both, and cooperate on matters that are common to them, the problem will remain.
} 
constitutional arrangement annihilated the rights of the Oromo over Addis Ababa/Finfinnee. The State of Oromia was effectively reduced to being like any other offices in Addis Ababa/Finfinnee - instead of giving, it was made to receive, and instead of hosting it become a guest to be hosted. ${ }^{17}$

Article 49 (5) of the FDRE constitution provides two fundamental principles (1) special interest and (2) joint administration. Under the special interest three elements are indicated: (i) the utilization of natural resources, ${ }^{18}$ (ii) the provision of social services; ${ }^{19}$ and (iii) other similar matters. ${ }^{20}$ In the last twenty-six years, what

${ }^{17}$ For the purpose of this article, the phrase "interest of Oromo" is used cautiously referring to the right to city of the Oromo - as a nation. Whereas, the "special interest of Oromia in Addis Ababa" is reductive and does not explicitly acknowledge the Oromo people's "right to city" - rather it depicts as a seeker of "special interest" which this article is critical of. However, Article 49 (5) of FDRE constitution is discussed here below for its symbolic importance.

18 The right to utilize natural resources is one of the special interests constitutionally allotted to the State of Oromia. In fact, in terms of natural resource utilization, Addis Ababa relies more on Oromia than Oromia on Addis Ababa. Nevertheless, for Oromia to maintain its access to any of natural resources in Addis Ababa/Finfinnee, this constitutional right should not be underestimated. Considering its symbolic significance, any law detailing this special right shall enlist any natural resources available in Addis Ababa (which are naturally available for human consumption) - among others: rocks (for mineral industry, for construction, underground water, etc.); air (for weather forecasting, wind power, etc.); water (for domestic consumption, recreation etc.); land (for burial places, parks, etc.); plants (for food, fibre, gums, pharmaceuticals, etc.); and forests (for timber, honey, seeds, etc.).

19 This is a very critical area where the interest of the State of Oromia in Addis Ababa/Finfinnee has been totally denied. Here, special interest shall be interpreted as "positive discrimination" where the State of Oromia shall receive favourable protection for allowing Addis Ababa/Finfinnee to be the seat of the Federal government. The most common social services include housing, education, health, water, transport and others.

${ }^{20}$ The phrase "other similar matters" stands for matters related to the utilization of natural resources as well as the provision of social services. If we take the concept of "social service" strictly, it may not include "public services." However, thanks to the phrase "other similar matters," social services can be extended to public services such as public libraries, auditoriums, museums, cinema halls, electricity, and roads. Some also argue that revenue 
form the social services and joint administration should take was neither indicated in the constitution nor in any subsequent legislation. Since the promulgation of the FDRE Constitution in 1995, there was not any serious attempt to come up with credible law to define what the term "special interest" means and how it should be implemented. ${ }^{21}$

The minutes of the FDRE constitution indicate that Article 49 (5) was adopted with 507 votes and 6 abstentions. Looking twenty-years back, the 6 abstainers were right, since they might have guessed that the provision would not have any practical significance whatsoever - thus "yeas" and "nays" would not change anything. Zelalem Abera expressed the real situation of land ownership in Oromia as follows:

"Qabeenyi biyya keenyaa, qabiyyeen qabeenyaa; yookaan qixxee hin taane yookaan cittee hin baane, akkuma isa adurii, akkuma isa durii !" (Poet, Zelalem Abera, 2000).

Literally, our country's wealth, of ownership, was neither equitably shared nor autonomously owned; but same as the past, same as the past! (Translation, mine)

Referring to the situation of the Oromo people in the historical past, the poet reifies that the reality of the Oromo people, as we speak, has remained the same that is, the Oromo could neither fully own their lafa (land) and biyya (country) independently nor owned jointly; rather their fate is being compromised heavily by power bearers. More importantly, from the prose one can see the continuity of the "accumulation by dispossession" and thus furthering the historical injustice.

sharing should be included within "other similar matters" (Article 49 (3) of the FDRE Constitution).

${ }^{21}$ Thus, for the last quarter of a century, the federal government has shown no interest to genuinely solve the issue of the "special interest of Oromia in Addis Ababa" (Article 49(5)). It is only when the demand from the Oromo mass protests pushes hard that the central government tries to "act." But, between 2013/14 to 2017/18, the "\#Oromo protests" heavily pressed the ruling party, EPRDF (Ethiopia People Revolutionary Front) and its surrogate party, OPDO (Oromo Peoples Democratic Organization) currently renamed as ODP (Oromo Democratic Party); and finally the master plan was aborted. 


\section{The Emasculated Principle of Joint Administration}

The principle of joint administration is very crucial for the State of Oromia to exercise its natural rights in Addis Ababa/Finfinnee. In the past quarter of a century, this principle was emasculated, since the State of Oromia had no municipal entity in Addis Ababa/Finfinnee. For the sake of joint administration, it is illogical to co-relate the Addis Ababa City Administration to the State of Oromia. The appropriate approach should be first legally establishing, through the Caffe (state council), an equivalent City Administration responsible to the State of Oromia. In the same way that the Addis Ababa/Finfinnee City Administration is responsible to the federal government, there should be a Finfinnee/Addis Ababa City Administration responsible to the State of Oromia. Before founding a joint administration, there has to be an analogous institution that could deal with, first and foremost, the affairs of Finfinnee/Addis Ababa as a capital of Oromia, and second, the special interest of Oromia in Addis Ababa/Finfinnee.

Put differently, where there is not a separate city administration directly responsible to the State of Oromia, it is structurally incongruent and constitutionally nonsensical to demand the State of Oromia to join hands with Addis Ababa/Finfinnee for joint administration. Instead, there has to be an analogous city administration directly responsible to the State of Oromia and could shoulder with Addis Ababa/Finfinnee City Administration. Besides, for the State of Oromia to ensure its "special interest" in Addis Ababa/Finfinnee - and above all, to say that it has a capital city - it should establish an equivalent body that can safeguard the interests of all Oromo in general, and those who live in Addis Ababa/Finfinnee in particular. Furthermore, the fact that there are already established special zones surrounding Addis Ababa/Finfinnee calls for a pragmatic policy that leverages the State of Oromia to proactively engage and garner the latter under the umbrella of an autonomous City Administration. This point is further discussed under the section dealing with two-city administration solution.

\section{Old Delhi and New Delhi: Example of Two-city Administration?}

Before picking India to draw a lesson from and to supplement the two-city administration proposal, this author has assessed some federal countries' capital cities ranging from U.S. to Switzerland and from Nigeria to India.

The author found that the case of India is more relevant than others for the following reasons. Like Ethiopia, India is a multicultural country; and like Oromia, Delhi, a state, hosts the federal and international institutions. As New Delhi is part and parcel of Delhi, so is Addis Ababa/Finfinnee for Oromia. However, unlike the 
State of Oromia, the Delhi government is not a guest in New Delhi; instead, Delhi exercises both autonomous and shared authority with the Government of India.

Delhi has an area of $1,483 \mathrm{sq} . \mathrm{km} .{ }^{22}$ Delhi possesses agriculturally fertile land, and the biggest market for agricultural as well as other fungible goods. Although many people think that New Delhi and Delhi are the same, they are actually two distinct entities. In Delhi there are two entirely different cities: an old Delhi which was the capital in the period of Islamic rule, and New Delhi, built by the British. New Delhi was designed as the capital of India in the early $20^{\text {th }}$ century as part of shifting the capital of the British Empire from Kolkata to Delhi. Following India's independence in 1947, New Delhi, which is to the South of old Delhi, remained the political capital of India. Delhi is a state and it has a governor. The federal Government of India and the government of Delhi administer New Delhi jointly. Although New Delhi is the seat of the government of India and a territory in Delhi, it is hard to draw a boundary between Delhi and New Delhi. However, the distinction exists between the two as New Delhi is a capital city hosting the Secretariat building, Parliament, UN regional offices, embassies, and consulates of other countries, etcetera. ${ }^{23}$

Literature indicates that Delhi was a single district National Capital Territory (NCT) until the mid-90s (Delhi Development Report 2009; Varshney, 1998). However, following the constitutional change in the early 1990s, the NCT was divided into nine districts and 27 sub-districts, and an equal number of tehsils (Ibid). Furthermore, following the 1991 NCT of Delhi Act Article 239 AA, the Delhi Transport Corporation was transferred from the Central Government to the Delhi government, and the Delhi Electricity Supply Undertaking and Delhi Water Supply and Sewage Disposal Undertaking have been transferred from Municipal Capital of Delhi to the Delhi Government (Ibid). Whereas, Delhi Metro Rail Corporation is a joint venture of the state-central government with the government of Delhi, and the central government has an upper hand in matters related to its governance (Ibid). It is also interesting to note that, whereas the development and management of land in Delhi is primarily with the Delhi Development Authority;

${ }^{22}$ Delhi is located in northern India between the latitudes of $28^{\circ}-24^{\prime}-17^{\prime \prime}$ and $28^{\circ}-53^{\prime}-00^{\prime \prime}$ North and longitudes of $76^{\circ}-50^{\prime}-24^{\prime \prime}$ and $77^{\circ}-20^{\prime}-37^{\prime \prime}$ East (Delhi Development Report, 2009).

${ }^{23}$ See: Difference Between Delhi and New Delhi| Difference Between http://www.differenc ebetween.net/miscellaneous/difference-between-delhi-and-new-delhi/\#ixzz53ZlcvvDE (Accessed on May 17, 2017). 
in New Delhi, the land belongs to Land and Estate department of the central government. In the New Delhi, the Law and order, and Police Administration are also under the central government.

For the purpose of civic administration, Delhi is divided into three autonomous distinct areas: the Delhi Municipal Corporation (known as DMC), the New Delhi Municipal Committee (NDMC), and the Delhi Cantonment Board (DCB) (Ibid). The DMC and NDMC are given the power to raise revenue by imposing property taxes, taxes on vehicles and animals, theatre taxes, taxes on advertisements other than those published in the newspapers, and duties on the transfer of property (Ibid: 64). The area falling within the jurisdiction of DCB and the NDMC is 43 and 42.73 square kilometres respectively. The rest of the National Capital Territory is covered by the MCD, which includes the rural areas. In terms of the constituting seats, the MCD members are elected councillors ranging from 80 and 134 to the maximum. In contrast, the NDMC is a body of eleven members, all nominated by the Central government. The Chairperson is a serving officer of the Government having the rank of Joint Secretary of the Government of India or above (Ibid). All the three municipal corporations have Mayors, Deputy Mayors, Chairman Standing Committees and Chairman for the committees formed for wards and other issues (Ibid: 7).

\section{A Blueprint towards Twin-city Administration}

Addis Ababa/Finfinnee is the home of diverse ethnic groups, the seat of international organizations, the seat of the federal government and the capital of the State of Oromia, at least in principle. ${ }^{24}$ Following Bangkok (capital of

${ }^{24}$ In fact, in the last century the population of Addis Ababa/Finfinnee grew exponentially. For instance, 2010 the total population was 65,000 in $1910,100,000$ in $1935,443,728$ in 1961, and 1,423,111 in 1984 and in 2015 it reached 3,194,000. Equally, in 1935 the geographic size of Addis Ababa/Finfinnee was 21, 8000 ha, in 1986 it grew to 53,014, in 1996 it become 54,000. Today, Addis Ababa/Finfinnee is eleven times larger than Adama city, the second largest city in Ethiopia. In addition, Addis Ababa has the "highest concentration of basic service facilities per population" (Zelalem Kibret, 2015). Currently, the total population residing in Addis Ababa is estimated to be 2.7 million (World Population Review, 2017). However, other sources estimate the population in Addis Ababa/Finfinnee to be seven million.

See: http://worldpopulationreview.com/countries/ethiopia-population/cities/(Accessed on July 17,2017$)$. In Ethiopia, only $19 \%$ of the population live in urban and the rest $(81 \%)$ live in rural area. 
Thailand) and Lima (capital of Peru), it is the third largest primate city in the world (Zelalem Kibret, 2015). Experiences of the South East Asian countries and most federal states in the world, primate cities are eliminated in favour of secondary city. Contrary to this, Addis Ababa/Finfinnee remained the primate as well as secondary city in Ethiopia (Ibid).

This trend has never been questioned and/or reversed. For instance, Article 5 of the Revised Addis Ababa City Charter reads that the boundaries of Addis Ababa City may either be settled based on the consensus of the Addis Ababa City Council and the State of Oromia, or by the Federal Government. The provision appears to be an intended loophole for encroachment on the territory of the State of Oromia. The fact that the administration of Addis Ababa/Finfinnee was made solely responsible to the Federal government (see: Article 49 (3)) has further crippled the State of Oromia from taking any significant action to contain the Federal Government's expansion, and the resulting environmental degradation (Dibaba 2012). ${ }^{25}$

To address these challenges, this paper proposes a two-city administration. Suppose that a proclamation entailing aforesaid issues and the special interest of the State of Oromia in Addis Ababa is enacted. The question is how such a proclamation could be enforced in the absence of an autonomous city administration responsible to the State of Oromia? This paper strongly advocates for the establishment of twin city system where Finfinnee/Addis Ababa City Administration is answerable to the Oromia Regional State and Addis Ababa/Finfinnee City Administration is answerable to the Federal government. The territorial jurisdiction of the former may encompass all Special Zones surrounding Addis Ababa/Finfinnee: Burayu, Dukem, Gelan, Holeta, Lege Tafo, Sendafa, Sebeta, and Sululta. ${ }^{26}$

\footnotetext{
${ }^{25}$ Whenever the people invoke their constitutional rights and demand just treatment as per the Constitutional framework - the government labels such quest as either "antidevelopment", "anti-peace" or as sympathizers with the Oromo Liberation Front (OLF), which the EPRDF used to regard it as terrorist organization. However, due to political change in Ethiopia, all political organizations, both armed and unarmed, are relieved of being regarded as terrorists.

${ }^{26}$ Regulation No.115/2000, Regulation issued to Establish the Special Zone of Oromia Around Finfine, Magalata Oromia, Finfine, August 2000.
} 
Where the dwellers from different walks of life in the Addis Ababa/Finfinnee, may be seen in light of the Bourdieu's "transformation of the forms of capital in sub-fields" (Bourdieu, 1993 quoted in Varli-Görk, 2014); the claim of the Oromo people living in the city signifies the "struggles ... to realize their material interests in the city (Logan and Molotch 1987 quoted in Varli-Görk, Reyhan. 2014). The claim of the Oromos in Addis Ababa/Finfinnee city might fit into the production of "separate urban space" (Purcell, 2002 and Isin, 2000 quoted in Varli-Görk, 2014: 139). In other words, it is the claim for the construction of "new relations" divorced from the old polity (Lefebvre, 1991 quoted in Varli-Görk, 2014: 145). In our case, the rationale of proposing the Finfinnee/Addis Ababa City Administration signifies the development of new "physical/perceived space", i.e. "objective reality" while the special interest of the State of Oromia in the old polity, i.e. Addis Ababa/Finfinnee, can still be treated as "mental/conceived space", i.e. "subjective reality" as well as "social/lived space", i.e. "actual reality" (Lefebvre, 1991: 12; Varli- Görk, 2014: 148).

At face value, this suggestion may appear shallow. However, this strategy would allow the State of Oromia to encircle Addis Ababa/Finfinnee and thus deter its limitless encroachment. Moreover, as the special zones contain numerous industries and development projects, there is a possibility that Addis Ababa/Finfinnee will dissect into political and economic centres. In other words, the Finfinnee/Addis Ababa City Administration would become an economic capital, whereas Addis Ababa/Finfinnee would remain a political capital.

It has to be noted that, in the absence of an equivalent body such as the Finfinnee/Addis Ababa City Administration, to aim for a joint administration (see Article 49(5) of FDRE Constitution) is contrary to a federal arrangement. In other words, for a joint administration to exist, $a b$ initio, there should be two separate but congruent organs. Once the Finfinnee/Addis Ababa City Administration is established, it should become directly accountable to the state of Oromia. In other words, on behalf of the State of Oromia, Finfinnee/Addis Ababa City Administration would deal with the Federal government on matters concerning the special interest of Oromia in Addis Ababa. Where the Finfinnee/Addis Ababa City Administration and the Addis Ababa/Finfinnee City Administration work jointly on matters that are common; and they act independent on matters specific to both of them. Thus, a joint administration could be established on matters that are shared -- for example, on matters such as the usage of natural resources, waste management, and environmental protection. On the other hand, the Addis Ababa/Finfinnee City Administration would not interfere in the affairs of the Finfinnee/Addis Ababa City Administration when it comes to the preservation and 
promotion of the culture, language, history, education, health, and other social services in Finfinnee/Addis Ababa. Likewise, the latter should not interfere into exclusive affairs of the Addis Ababa/Finfinnee City Administration. Nevertheless, both should have the concurrent power of levying and collection of taxes (Article 98 and 99 of FDRE Constitution).

It is important to elaborate how self-rule and shared rule could work in twincity system. First and foremost, the Finfinnee/Addis Ababa City Administration headquarters must be established in Addis Ababa. This signifies the "conceived reality" - mirroring the symbolic significance of Finfinnee/Addis Ababa for the State of Oromia. Second, it should be noted that the Finfinnee/Addis Ababa City Administration represents all Oromos living in Finfinnee/Addis Ababa and beyond. As such, any Oromo who lives in any sub-city would seek social services from the Finfinnee/Addis Ababa City Administration - and the latter is duty bound to deliver them. All Oromo people who live under the jurisdiction of Addis Ababa/Finfinnee City Administration may receive social services that were provided and managed by the latter; whereas, the Finfinnee/Addis Ababa City Administration would oversee if their constitutional right is safeguarded. Third, respective city administrations should have city councils with the power and responsibility to review and approve the annual budget, oversee the performance of the local public employees, borrow funds, modify the city's charter, exercise the power of eminent domain, ${ }^{27}$ and communicate policies and programs to residents and others ${ }^{28}$ (Fromont, 1978 quoted in Azuela and Herrera-Martín, 2009: 7).

The relationship between the Addis Ababa/Finfinnee City Administration and the Finfinnee/Addis Ababa City Administration can be framed as autonomous but interdependent "legal persons" - established with distinguished purposes. As legal persons, they would have powers, functions, and capitals. The budgets allocated to each administration depends on the scope of social services to be provided, and should be guided by the principle of "subsidiarity" (Endo, 1998). As legal persons, among others, they shall exercise juridical powers attributed to them by the law. In particular, the Finfinnee/Addis Ababa City Administration would issue and implement policies concerning the development of the city; constitute the

\footnotetext{
${ }^{27}$ It is important to note here that there could be no urban policies without the acquisition and control of land by public authorities.

28 See also Council Functions http://www.nlc.org/city-councils (Accessed on June 26, 2017).
} 
executive body of the City Government and establish public enterprises, as legal entities, on its own or in partnership, as per applicable laws, with the private sector or other third parties. It would organize Sub-Cities and Kebeles, demarcate their borders and allocate budgetary subsidy to them; administer, according to law, the land and the natural resources located within the bounds of the City; and prepare, approve and administer the budget of the City. It would determine and collect, according to law, taxes, duties and service charges out of the sources of income. Finally, under authorization by the state of Oromia, the Finfinnee/Addis Ababa City Administration could borrow money from third bodies; establish co-operation agreements with Addis Ababa/Finfinnee City Administration, federal government and regional government organs, the private sector, non-governmental organizations, and various international organizations. ${ }^{29}$

The Finfinnee/Addis Ababa City Administration would have a city council that would constitute the executive organs of the City, approve the budget of the City Government, issue the Master plan of the City, elect, from among its members, the City Mayor and Deputy Mayor, approve the appointment of members of the City Cabinet upon the recommendation of the Mayor, approve, the appointment of the President, Vice President and judges of the City Courts and of the Chief Auditor; and establish the Judicial Administration Commission and designate its members. ${ }^{30}$ In turn, the Mayor of the Finfinnee/Addis Ababa City Administration, being accountable to the City Council and the Government of Oromia, would be the Chief Executive Officer of the City.

Most importantly, the Finfinnee/Addis Ababa City Administration would generate revenue through taxes, fees, rentals, royalties, etcetera and through joint investment, fund investment, and donations. It could borrow from domestic sources, directly or by selling bonds. It could establish a Savings and Development Bank in partnership with governmental and non-governmental organizations. Furthermore, it could receive financial assistance from the Federal as well as the state government. ${ }^{31}$

${ }^{29}$ See: Article 11 of Proclamation No.361/2003, Addis Ababa City Government Revised Charter, Federal Negarit Gazeta, 9th Year No.86, Addis Ababa.

${ }^{30}$ See also: Article 12 of Addis Ababa City Government Revised Charter Proclamation No. $361 / 2003$.

${ }^{31}$ See also: Article 53ff of Addis Ababa City Government Revised Charter Proclamation No. 361/2003. 
Last but not the least, it comes to the security and justice system, the Finfinnee/Addis Ababa City Administration, as a component part of the State of Oromia, would be accountable to the State Government. The Government of Oromia would have the power to dissolve the Finfinnee/Addis Ababa City Administration and to constitute a transitional administration, as per the decision of the Caffee, where an act endangering the state constitution is committed by the Finfinnee/Addis Ababa City Administration Councillors, where it fails to manage security matters and emergency situations. ${ }^{32}$

\section{Concluding Remarks}

This paper discussed that Addis Ababa/Finfinnee is a nucleus of political fever in Ethiopia. It evaluates the historical injustice and the recent past displacement of the Oromo people in and surrounding of Addis Ababa/Finfinnee in the name of "development"; and discussed the widespread discontents in relation to land rights in general and Oromia Regional State's constitutional rights in its Capital city in particular. As stated elsewhere, although the State of Oromia has "special interest" in Addis Ababa/Finfinnee, in effect, this constitutional provision was kept merely a promissory note. Perhaps, it is only when mass protests from the people take place that it gains some momentum. Most of the time, under the TPLF-led EPRDF, the pressure from the public is often appeased through political manoeuvres and government brutalities.

Under Article 49 (5) of FDRE Constitution, although what constitutes the "special interest" is broadly stated, its details are neither defined nor enacted into law. In fact, this paper does not object a legislation that would safeguard the interest of Oromia in Addis Ababa/Finfinnee. Rather, a fortiori, it proposes a structural adjustment from the side of the State of Oromia. That is, devising an autonomous Finfinnee/Addis Ababa City Administration responsible to the State of Oromia, which can ensure the special interest of the latter in Addis Ababa/Finfinnee and ultimately constituting twin-city system. Through such a strategic and legitimate move the unjust historical relations between the central government and the Oromo people could be rectified. In addition, it may change the prey-predatory relationship into a relationship of mutual interdependence. Moreover, establishing such congruent and equivalent body allows it to delineate the uncontrolled elasticity of the capital city and defends the unjust eviction of the

32 See also Article 61 and ff of Addis Ababa City Government Revised Charter Proclamation No. 361/2003 
Oromo community surrounding Addis Ababa. By doing so, the State of Oromia ensures its constitutional right to self-rule. Furthermore, this mechanism decentralizes power and allows co-management between the federal government and the State of Oromia.

Last but not the least, for the implementation of such a proposal, the author is of the opinion that there should be deliberative forums, public discussions and stakeholders feedbacks on its relevance, efficacy as well as sustainability. Especially, the mayors of Finfinnee Special Zones, Oromia Regional State, the Federal Government and Addis Ababa/Finfinnee City government should deliberate over the powers and functions Finfinnee/Addis Ababa City administration vis-à-vis Addis Ababa/Finfinnee City Administration. Finally, where the Caffee enacts a proclamation founding the Finfinnee/Addis Ababa City Government capable of producing its own charter; Addis Ababa/Finfinnee City government amends its charter congruent to the former. 


\section{References}

Addis, A. (2006). Environmental Protection Authority National Capacity Needs Self-assessment Action Plan Part I: (Stocktaking Report). Addis Ababa, Ethiopia.

Azuela, Antonio and Herrera-Martín, Carlos. (2009). "Taking Land around the World: International Trends in Expropriation for Urban and Infrastructure Projects" In Somik V. Lall \& et.al. (eds.). Urban Land Markets Improving Land Management for Successful Urbanization: Springer.

Bulatovich, Alexander. (2000). Ethiopia through Russian Eyes: A Country in Transition: 1896-1898. Translated by Richard Seltzer. Red Sea Press.

Dibaba, Betru. (2012). Constitutional Special Interest of the State of Oromia in Addis Ababa City Administration. Retrieved from: https://www.http://www.abyssinialaw.com/blogposts/item/1611 constitutionalspecial-interest-of-oromia (Accessed June 20, 2017).

Endo, Ken. (1998). "The Art of Retreat: A Use of Subsidiarity by Jacques Delors 1992-93." Hokkaido University Collection of Scholarly and Academic Papers (HUSCAP), 48(6): 378-394.

Erdi-Lelandais, Gülçin. (2014). Understanding the City: Henri Lefebvre and Urban Studies. UK: Cambridge Scholars Publishing.

Gemetchu Megersa . (1993). Knowledge, Identity and the Colonizing Structure the Case of The Oromo in East and Northeast Africa ( $\mathrm{PhD}$ Dissertation). University of London: School Of Oriental and African Studies.

Harris, Major W.C. (1844). The Highlands of Ethiopia. New York: J. Winchester. Harvey, David. (2012). Rebel Cities: From the Right to the City to the Urban Revolution. London \& New York: Verso.

Harvey, David. (2008). "The Right to the City. New left review" NLR, 53.

IDMC (International Displacement Monitoring Centre). (2010). Internal displacement in Africa: A development challenge Exploring development initiatives to alleviate internal displacement caused by conflict, violence and natural disasters. (See: http://www.internal-displacement.org/assets/publications/2012/201210-afinternal-displacement-in-africa-development-challenge-thematic-en.pdf (Accessed on January 12, 2017).

Makki, Fouad. (2013). Development by Dispossession: Terra Nulliusand the SocialEcology of New Enclosures in Ethiopia. Rural Sociology, 79 (1): 79-103.

Lefebvre, H. (1991). The Production of Space. Translated by Nicholson-Smith, D. Oxford: Blackwell.

Varli-Görk, Reyhan. (2014). "The Transformation of Antalya into a City of Culture: An Attempt at Rhythm analysis" In Gülçin Erdi-Lelandais (ed.), 
Understanding the City: Henri Lefebvre and Urban Studies. Cambridge Scholars Publishing.

Markakis, John. (2011). Ethiopia: The last two frontiers. London: James Currey.

Muradu Abdo Srur. (2014). State Policy and Law in Relation to Land Alienation in Ethiopia (A Thesis Submitted in Partial Fulfilment of the Requirements of the Degree of Doctor of Philosophy in Law). University of Warwick, School of Law. (See: http://wrap.warwick.ac.uk/74132/1/WRAP THESIS Spur 2014.pdf. (Accesse d on May 18, 2017).

Oromo Studies Association (OAS). (December 9, 2015). Statement on the Addis Ababa Integrated Development Master Plan and Oromo Student Protests against its Implementation. Retrieved from:

https://oromiatimes.org/2015/12/10/osa-wqo-statement-on-the-addis-ababaintegrated-development-master-plan-and-oromo-student-protests-against-itsimplementation/

Purcell, Mark. (2002). "Excavating Lefebvre: The right to the city and its urban politics of the inhabitant." Geo Journal, 58: 99-108.

Rajack, Robin and Lall, Somik V. (2009). "Introduction: What Do We Know About Urban Land Markets?" In: Somik V. Lall \& et al., (eds.). Urban Land Markets: Improving Land Management for Successful Urbanization. Springer.

Regassa, Tsegaye. (2016). Ethiopia: The Special Interest - The Affirmation of Denial. http://allafrica.com/stories/201601260577.html(Accessed May 25, 2017).

Samara, Tony Roshan and et. al. (2013).“Introduction.” In: Tonny. R. Samara, Shenjing He and Guo Chen, (eds.). Locating Right to the City in the Global South.London and New York: Routledge.

Varli-Görk, Reyhan. (2014). "The Transformation of Antalya into a City of Culture: An Attempt at Rhythm analysis." In Gülçin Erdi-Lelandais, (ed.). Understanding the City: Henri Lefebvre and Urban Studies, UK: Cambridge Scholars Publishing.

Varshney, Ashutosh. (1998). Urban-rural struggles in India Democracy, development, and the countryside: Cambridge Studies in Comparative Politics. Cambridge University Press, UK.

World Charter Right to the City (WCRC).(2005).

See: http://www.righttothecityplatform.orbr/download/publicacoes/World\%20Charter \%20for\%20the\%20Right\%20to\%20the\%20City.pdf (Accessed on May 26, 2017).

Zelalem Kibret. (2015). 不 See also: http://www.zoneniners.com/2015/12/blog-post_28.html (Accessed on December 18, 2018). 